\title{
Expression of the Autoimmune Regulator Gene and Its Relevance to the Mechanisms of Central and Peripheral Tolerance
}

\author{
Roberto Perniola \\ Neonatal Intensive Care, Department of Pediatrics, V. Fazzi Regional Hospital, Piazza F. Muratore, 73100 Lecce, Italy \\ Correspondence should be addressed to Roberto Perniola, rperniola@hotmail.com
}

Received 14 June 2012; Revised 26 August 2012; Accepted 11 September 2012

Academic Editor: Shervin Assassi

Copyright () 2012 Roberto Perniola. This is an open access article distributed under the Creative Commons Attribution License, which permits unrestricted use, distribution, and reproduction in any medium, provided the original work is properly cited.

The autoimmune polyendocrine syndrome type 1 (APS-1) is a monogenic disease due to pathogenic variants occurring in the autoimmune regulator (AIRE) gene. Its related protein, AIRE, activates the transcription of genes encoding for tissue-specific antigens (TsAgs) in a subset of medullary thymic epithelial cells: the presentation of TsAgs to the maturating thymocytes induces the apoptosis of the autoreactive clones and constitutes the main form of central tolerance. Dysregulation of thymic AIRE expression in genetically transmitted and acquired diseases other than APS-1 may contribute to further forms of autoimmunity. As AIRE and its murine homolog are also expressed in the secondary lymphoid organs, the extent and relevance of AIRE participation in the mechanisms of peripheral tolerance need to be thoroughly defined.

\section{Introduction}

Pathogenic variants in the autoimmune regulator (AIRE) gene cause the autoimmune polyendocrine syndrome type 1 (APS-1), also called autoimmune polyendocrinopathycandidiasis-ectodermal dystrophy (APECED), an autosomal recessive disease characterized by immunological disturbances such as difficulty to eradicate surface candidiasis and autoimmunity to various organs, mainly endocrine glands $[1,2]$. AIRE is located in the region q22.3 of chromosome 21 [3], and its cloning dates back to the second half of the nineties $[4,5]$. APS- 1 is a rare model of monogenic autoimmune disease and in this quality provides unequivocal insights into the pathogenesis of more complex diseases of analogous nature $[6,7]$.

Due to its biochemical properties, AIRE protein activates the transcription of genes encoding for tissue-specific antigens (TsAgs) in a subset of medullary thymic epithelial cells (mTECs): this phenomenon, called promiscuous gene expression (PGE), is finalized to the promotion of central (thymic) tolerance [8]. The last step of the process is represented by the deletion (negative selection) of T-cell clones bearing T-cell receptors (TCRs) with critical degree of specificity for the corresponding TsAgs [9].
Nonetheless, the nature and extent of AIRE action remain unclearly defined. A rigorous mapping of AIRE gene expression is fundamental to the dissection of the protein role, but the current data show several incongruities, presumably due to differences in tissue substrate and sensitivity of the methods utilized.

Here an extensive review of the studies pertaining to the argument is reported, with an additional look at the relation between disturbances in AIRE expression and diseases other than APS-1 in human field and animal models.

\section{The Initial Studies}

2.1. Initial Mapping of AIRE Expression. The first two studies, which dealt with AIRE cloning and searched for AIRE mRNA in bulk tissue samples by Northern blotting $(\mathrm{NB})$, gave disagreeing responses $[4,5]$. Although the thymus showed the highest level of positivity in both cases, one research group found a further weak positivity only in lymph-nodal, fetal liver, and appendix samples [4], while the other one signaled also a moderate to strong positivity in the samples from bone marrow, spleen, peripheral blood lymphocytes (PBLs), and organs such as thyroid, pancreas, 
adrenal gland, and testis, in other words the endocrine glands targeted by autoimmunity in APS-1 [5].

2.2. Identification of AIRE-Expressing Cell Lineages. Later, the same research groups stated that the highest amount of AIRE mRNA and AIRE protein could be identified, by in situ hybridization (isH) and immunohistochemistry (IHC), in rare cells scattered in the medulla and subcapsular area of the thymus, or buried in the Hassall's corpuscles $[10,11]$.

In immunofluorescence (IF), these cells were seen to express surface markers such as cytokeratins, molecules of the class-II major histocompatibility complex (MHC-II), and the clusters of differentiation CD80, CD86, and CD40, and for this reason were recognized as mTECs, the main components of the thymic stroma. A minority of thymic AIRE $^{+}$cells expressed CD11c and CD83, which identify mature dendritic cells (DCs) of myeloid lineage [10].

In the secondary lymphoid organs, one research group detected AIRE only in the medulla and paracortical area of the lymph nodes, in the spleen and fetal liver: similarly to thymic DCs, lymph-nodal AIRE ${ }^{+}$cells expressed CD83, suggesting a common identity [10].

In contrast, the other group observed significant staining of medullary thymocytes, lymph-nodal and splenic red-pulp lymphocytes, and PBLs; other leukocyte populations, such as neutrophilic granulocytes and monocytes, were also $\mathrm{AIRE}^{+}$. The results, obtained by $\mathrm{IHC}$ and immunocytochemistry (ICC), were confirmed by quantitative real-time reverse transcriptase-polymerase chain reaction (RT-PCR) [11].

By IF, freshly isolated PBLs were positively stained for AIRE in the study of Rinderle et al. too [12].

\section{AIRE Expression in the Cells of the Immune Response and in Nonlymphoid Organs}

The initial studies set in motion the debate, still outstanding, on the existence of cell lineages, complementary to mTECs, in which AIRE would be expressed, and the related meaning. As expected, such debate primarily deals with AIRE expression in the cells of the immune response.

3.1. AIRE Expression in the Monocyte/DC Lineage. Measurable amounts of AIRE mRNA and AIRE protein were evidenced in $\mathrm{CD} 14^{+}$cells sorted from peripheral blood, and in monocyte-derived DCs through in vitro differentiation [13-15], with isolated exceptions [16]. One of these research groups found AIRE mRNA also in plasmacytoid DCs isolated directly from the peripheral blood [15]. Members of the mitogen-activated protein kinase (MAPK) family would be involved in the signal-transduction pathway allowing AIRE expression in the monocyte/DC lineage $[14,17]$. Interestingly, it was observed that DC maturation is paralleled by increasing AIRE levels and ordinary up-regulation of several genes [14].

Later, Poliani et al. detected AIRE expression in frozen samples of lymph nodes and gut-associated lymphoid tissue (GALT) from adult subjects, while the fetal samples were negative: the cells responsible for such positivity expressed surface markers typical of mature DCs [18].

3.2. AIRE Expression in the Lymphocyte Lineage. AIRE expression in the lymphocyte lineage remains quite uncertain: reappraising and partly correcting their previous findings [13], Nagafuchi et al. found, by RT-PCR, AIRE mRNA in PBLs belonging to the $\mathrm{CD} 4{ }^{+} \mathrm{T}$-cell subset; the transcription level increased under antigen- or cytokine-mediated activation [19]. Another Japanese research group detected AIRE mRNA in thymic B lymphocytes and double-positive (DP) $\mathrm{CD}^{+} \mathrm{CD}^{+}$thymocytes, while in the peripheral blood it was restricted to B lymphocytes only [20].

3.3. AIRE Expression in Nonlymphoid Organs. In two of the above studies, a large set of human organs was assayed by RT-PCR and IHC, and the authors agreed that organs of the endocrine, cardiovascular, respiratory, gastrointestinal, genitourinary, and nervous systems are either consistently negative or negligibly positive for AIRE expression $[16,18]$. Based on the observation that mTECs and cancer cells share PGE, Klamp et al. included RT-PCR of samples from human cancers, but no AIRE expression was found [16].

So, to recapitulate, only Finnish researchers detected AIRE mRNA in human tissues such as endocrine glands and other nonlymphoid organs, albeit the cell lineages detaining such property were not defined [5].

3.4. Unexpected Localizations. An unexpected localization of AIRE mRNA was found by Harris et al., who studied two unrelated APS-1 adolescents with chronic abnormalities of endochondral ossification, characterized by irregular and radioopaque metaphyses, subjacent to the growth plates of long bones; AIRE expression, although not searched for in the bone samples of the patients, was assayed in the thymus, liver, and growth plates of healthy fetuses aborted at 13-18 weeks of gestational age, in chondrocytes and in two chondrosarcoma lines: in all examined tissues, AIRE expression resulted consistently active. In particular, in the growth plate of the knee, AIRE mRNA appeared at 15 weeks of gestational age and was still present at 18 weeks [21].

Similar considerations may be done for AIRE expression in epidermal keratinocytes, in keratinocytes of the outer and inner epithelial sheaths of the hair follicle, and in matrix melanocytes $[22,23]$. At this level, AIRE is identifiable at 16 weeks of gestational age and colocalize with cytokeratin 17, a protein constitutive of the intermediate filaments [23].

The meaning of AIRE expression in chondrocytes and keratinocytes remains quite obscure. Intriguingly, Clark et al. had already proven that human skin cells (keratinocytes and fibroblasts), once cultured in a three-dimensional arrangement resembling the thymic architecture, have AIRE expression, synthesize a large set of TsAgs, and are able to perform a thymus-like function in de novo maturation and negative selection of T lymphocytes [24]. Currently, the demonstration that this observation may have some in vivo equivalence is lacking. 
Findings pertaining to AIRE expression in human tissues are resumed in Table 1.

\section{Aire Expression in the Mouse}

Researches on the murine homolog (Aire, printed in lower case to avoid confusion) recapitulate most findings and incongruities encountered in dealing with human tissues, as resumed in Table 2.

4.1. Searching for Aire mRNA. Not surprisingly, the low level of Aire expression made some methods, such as NB, unsuitable to detect Aire mRNA even in the thymus [25-27].

On the other hand, RT-PCR gave consistently positive results on the thymus [26-33], lymph nodes [28-30], spleen [26, 28-32], and liver [28, 29, 32].

Performing RT-PCR on the cells obtained by enzymatic digestion of whole thymus and spleen, and sorted by flow cytometry, Heino et al. found Aire mRNA in mTECs and, to a lesser degree, in DCs: further analysis of the latter revealed Aire transcription in two thymic $\left(\mathrm{CD} 8 \alpha^{+}\right.$and $\left.\mathrm{CD} 8 \alpha^{-}\right)$and three splenic $\left(\mathrm{CD} 4^{+} \mathrm{CD} 8 \alpha^{-}, \mathrm{CD} 4^{-} \mathrm{CD} 8 \alpha^{-}\right.$and $\left.\mathrm{CD} 4{ }^{-} \mathrm{CD} 8 \alpha^{+}\right)$subsets of myeloid and lymphoid lineage [28].

RT-PCR demonstrated higher sensitivity than is H that, when employed to map Aire expression on tissue sections, detected Aire mRNA only in rare foci of mTECs of murine embryos (from 14.5 days after conception), and young and adult mice $[25,26,32]$.

On the other hand, a Finnish research group observed, by is $\mathrm{H}$, an additional staining of a small number of medullary thymocytes, and of the lymph-nodal paracortical zone, the splenic red pulp, and immature bone marrow elements belonging to various cell lineages [29]. In the same study, RTPCR detected AIRE mRNA in a remarkable number of organ samples [29].

4.2. Searching for Aire Protein. Aire protein was found by Western blotting (WB) in the only thymus $[28,32]$; by IHC, Heino et al. observed that Aire ${ }^{+}$cells belonged to a subset of mTECs, distributed among resting $(60 \%)$ and activated (30\%) elements, as revealed by CD95 and CD29, respectively. In embryonic thymus, Aire ${ }^{+}$cells appeared at 14 days after conception [28]. In the same study, IHC was unable to stain Aire $^{+}$cells in any other tissue examined, albeit RT-PCR had detected Aire mRNA in the lymph nodes and spleen after the first round of amplification, and in the liver and various other organs after two rounds of the procedure [28].

Conversely, reproducing the results of RT-PCR, Halonen et al. found Aire ${ }^{+}$cells in several organs [29]. In a following study, the authors strengthened these results by comparing tissue reactivity in wild-type and Aire-deficient $\left(\right.$ Aire $\left.^{-/-}\right)$ mice [34]. The findings were later supported by a UK research group [32].

It should be underlined that almost all cited studies utilized polyclonal antibodies (Abs) from mouse or rabbit to stain $\mathrm{AIRE}^{+} / \mathrm{Aire}^{+}$cells in human and murine tissues, respectively, while the use of monoclonal Abs was rare and gave a restricted positivity $[10,18]$.
In this sense, Hubert et al., using rabbit monoclonal antiAire Abs, found Aire ${ }^{+}$cells among murine mTECs only, albeit in the same study Aire mRNA had been detected also in thymic and splenic DCs [35]. Then the authors formulated an unifying theory, hypothesizing that the amount of Aire mRNA detected could be below the critical level useful to induce the translation into its protein, and that only monoclonal anti-Aire Abs would allow fine and unequivocal mapping of true Aire expression. It was not excluded that some extrathymic cells may express Aire in particular, not yet fully known, conditions [35].

4.3. Other Relevant Localizations. Two research groups identified, in the stroma of lymph nodes (and, in one instance, spleen), Aire ${ }^{+}$cells that exhibited a $\mathrm{CD} 45^{-} \mathrm{CD} 80^{-}$ CD86 ${ }^{-}$MHC-II ${ }^{+}$phenotype with further, albeit not coincident, epithelial-cell markers. Such cells were able to induce the deletion of $\mathrm{CD} 8^{+}$T-cell clones bearing TCRs specific for antigens encoded by Aire-dependent genes: the clones had been transferred into irradiated mice reconstituted with $\beta_{2}$-microglobulin-deficient $\left(\beta_{2}-m^{-/-}\right)$bone marrow to ensure that only radioresistant stromal cells of the secondary lymphoid organs could interact with them [36,37].

Searching for Aire expression in lymph-nodal and splenic stroma by other research groups did not produce unequivocal results [31,38-40]. The localization of Aire in secondary lymphoid organs may be connected to not yet defined mechanisms of peripheral tolerance integrating the thymic function by enlarging the set of controlled genes, deleting autoreactive T-cell clones that escape thymic deletion, or both $[41,42]$.

In another study, RT-PCR and IHC were used to demonstrate Aire transcription and translation in spermatogonia and early spermatocytes, where Aire would play a role in the program of early, scheduled apoptosis indispensable to the maintenance of germline stability [43].

Findings and controversies over the extrathymic expression of human AIRE and its murine homolog have been reviewed by Eldershaw et al. [44].

\section{Regulation of AIRE Expression}

5.1. Signal-Transduction Pathways. Besides to the integrity of the gene in itself, thymic AIRE expression requires that of two signal-transduction pathways enabling heterodimeric nuclear transcription factors known as NFs- $\kappa \mathrm{B}$ : NF- $\kappa \mathrm{B} 1$ includes a protein, p50 (from p105 precursor), and the transcription factor reticuloendotheliosis viral oncogene homolog A (RelA), while NF- $\kappa$ B2 includes protein p52 (from p100 precursor) and another member of Rel family, RelB. In epithelial-cell lineages, NFs- $\kappa \mathrm{B}$ control cell proliferation, differentiation, and survival [45].

Thymic intercellular signaling promotes the pathways: at least three members of tumor necrosis factor (TNF)receptor family represented on mTEC surface, namely CD40, receptor activator of NFs- $\kappa$ B (RANK) and LT- $\beta$ receptor (where LT stays for lymphotoxin), are able, by interaction with their respective partners on $\mathrm{CD}^{+}$thymocytes, namely 
TABLE 1: AIRE expression (AIRE mRNA and AIRE protein) in human extra-thymic systems, organs, and tissues.

\begin{tabular}{|c|c|c|c|c|}
\hline \multirow{2}{*}{ Systems, organs, tissues } & \multicolumn{2}{|c|}{ AIRE expression negative or negligibly positive } & \multicolumn{2}{|c|}{ AIRE expression moderately or strongly positive } \\
\hline & Techniques & Cell types & Techniques & Cell types \\
\hline Bone marrow & $\begin{array}{l}\text { NB [4] } \\
\text { RT-PCR [18] } \\
\text { IHC [18] }\end{array}$ & & NB [5] & \\
\hline Lymph nodes & $\begin{array}{l}\text { IHC [18] } \\
\text { FC [20] }\end{array}$ & $\begin{array}{l}\text { CD14 }{ }^{-} \text {cells [20] } \\
\text { B lymphocytes [18] } \\
\text { T lymphocytes [18] } \\
\text { Monocytes [18] } \\
\text { Macrophages [18] } \\
\text { DCs (plasmacytoid) [18] } \\
\text { Epithelial cells [18] } \\
\text { Endothelial cells [18] }\end{array}$ & $\begin{array}{l}\text { NB }[4,5] \\
\text { isH }[10] \\
\text { RT-PCR }[16,18] \\
\text { IHC }[10,11,18] \\
\text { IF }[10] \\
\text { FC }[20]\end{array}$ & $\begin{array}{l}\text { Neutrophilic granulocytes [11] } \\
\text { Lymphocytes [11] } \\
\text { CD14 }{ }^{+} \text {cells }[20] \\
\text { DCs (myeloid-lineage) }[10,18]\end{array}$ \\
\hline Spleen & $\begin{array}{l}\text { NB }[4] \\
\text { RT-PCR } \\
{[16,18]} \\
\text { IHC }[18] \\
\end{array}$ & & $\begin{array}{l}\text { NB }[5] \\
\text { isH }[10] \\
\text { IHC }[10,11]\end{array}$ & $\begin{array}{l}\text { Neutrophilic granulocytes [11] } \\
\text { Lymphocytes (red-pulp) [11] }\end{array}$ \\
\hline GALT & & & $\begin{array}{l}\text { RT-PCR [18] } \\
\text { IHC [18] }\end{array}$ & \\
\hline Fetal liver & & & $\begin{array}{l}\text { NB }[4,5] \\
\text { isH }[10] \\
\text { IHC }[10]\end{array}$ & \\
\hline
\end{tabular}

\begin{tabular}{|c|c|c|c|c|}
\hline Adult liver & $\begin{array}{l}\text { NB }[4] \\
\text { isH }[10] \\
\text { RT-PCR } \\
{[16,18]} \\
\text { WB }[12] \\
\text { IHC }[10,18]\end{array}$ & & & \\
\hline Peripheral blood leukocytes & $\begin{array}{l}\text { NB }[4] \\
\text { RT-PCR } \\
{[13,16,19]} \\
\text { ICC }[10,13] \\
\text { FC }[20]\end{array}$ & $\begin{array}{l}\text { Neutrophilic granulocytes [13] } \\
\text { PBMCs [16] } \\
\text { CD14- cells [16] } \\
\text { B lymphocytes [19] } \\
\text { T lymphocytes }[20] \\
\text { CD4 } 4^{+} \text {T lymphocytes }[13,20] \\
\text { CD8 }{ }^{+} \text {T lymphocytes }[19,20] \\
\text { Monocytes }[16,19] \\
\text { DCs (myeloid-lineage) }[16]\end{array}$ & $\begin{array}{l}\text { NB }[5] \\
\text { RT-PCR } \\
{[11,13-15,19,20]} \\
\text { ICC }[11,13] \\
\text { IF }[11,12] \\
\text { FC }[20]\end{array}$ & $\begin{array}{l}\text { Neutrophilic granulocytes [11] } \\
\text { PBMCs }[11,13,19] \\
\text { PBLs }[11,12] \\
\text { B lymphocytes }[20] \\
\text { T lymphocytes }[19,20] \\
\text { CD4 } 4^{+} \text {T lymphocytes }[19] \\
\text { CD14 cells }[20] \\
\text { Monocytes }[11,13,14] \\
\text { DCs (myeloid-lineage) } \\
{[13-15,19]} \\
\text { DCs (plasmacytoid) }[15]\end{array}$ \\
\hline Skeletal muscle & $\begin{array}{l}\text { RT-PCR } \\
{[16,18]} \\
\text { IHC }[18]\end{array}$ & & & \\
\hline Cartilage and bone & $\begin{array}{l}\text { RT-PCR } \\
{[16,18]} \\
\text { IHC }[18] \\
\end{array}$ & & RT-PCR [21] & Chondrocytes [21] \\
\hline Heart and blood vessels & $\begin{array}{l}\text { isH [10] } \\
\text { RT-PCR [18] } \\
\text { IHC }[10,18] \\
\end{array}$ & & & \\
\hline $\begin{array}{l}\text { Respiratory system (upper } \\
\text { and lower tract) }\end{array}$ & $\begin{array}{l}\text { isH }[10] \\
\text { RT-PCR } \\
{[16,18]} \\
\text { IHC }[10,18]\end{array}$ & & & \\
\hline \multirow{2}{*}{ Systems, organs, tissues } & \multicolumn{2}{|c|}{ AIRE expression negative or negligibly positive } & \multicolumn{2}{|c|}{ AIRE expression moderately or strongly positive } \\
\hline & Techniques & Cell types & Techniques & Cell types \\
\hline $\begin{array}{l}\text { Gastrointestinal system } \\
\text { (upper tract, small and large } \\
\text { bowel, salivary glands) }\end{array}$ & $\begin{array}{l}\text { RT-PCR } \\
{[16,18]} \\
\text { IHC }[18]\end{array}$ & & NB [4] & \\
\hline
\end{tabular}


TABle 1: Continued.

\begin{tabular}{|c|c|c|c|}
\hline $\begin{array}{l}\text { Endocrine glands } \\
\text { (parathyroid glands, thyroid, } \\
\text { pancreas, adrenal gland) }\end{array}$ & $\begin{array}{l}\text { NB }[4] \\
\text { isH }[10] \\
\text { RT-PCR } \\
{[16,18]} \\
\text { WB }[12] \\
\text { IHC }[10,18]\end{array}$ & NB [5] & \\
\hline $\begin{array}{l}\text { Genito-urinary system, } \\
\text { placenta, mammary gland }\end{array}$ & $\begin{array}{l}\text { isH [10] } \\
\text { RT-PCR } \\
{[16,18]} \\
\text { IHC }[10,18]\end{array}$ & NB [5] & \\
\hline Skin and annexes & $\begin{array}{l}\text { isH [10] } \\
\text { RT-PCR } \\
{[16,18]} \\
\text { IHC }[10,18]\end{array}$ & $\begin{array}{l}\text { RT-PCR [22] } \\
\text { IF }[22,23]\end{array}$ & $\begin{array}{l}\text { Keratinocytes (epidermal and } \\
\text { HF) }[23]\end{array}$ \\
\hline $\begin{array}{l}\text { Central and peripheral } \\
\text { nervous system }\end{array}$ & $\begin{array}{l}\text { RT-PCR } \\
{[16,18]} \\
\text { IHC }[18] \\
\end{array}$ & & \\
\hline Eye and annexes & $\begin{array}{l}\text { RT-PCR [18] } \\
\text { IHC [18] }\end{array}$ & & \\
\hline
\end{tabular}

AIRE: autoimmune regulator, GALT: gut-associated lymphoid tissue, PBMCs: peripheral blood mononuclear cells, PBLs: peripheral blood lymphocytes, DCs: dendritic cells, HF: hair-follicle, CD: cluster of differentiation, NB: Northern blotting, isH: in situ hybridization, RT-PCR: reverse transcriptase-polymerase chain reaction, WB: Western blotting, IHC: immunohistochemistry, ICC: immunocytochemistry, IF: immunofluorescence, and FC: flow cytometry.

CD40 ligand, RANK ligand and LT- $\alpha_{1} \beta_{2}$, and by means of TNF-receptor-associated factors (TRAFs), to initiate the cascade of reactions ending in NF- $\kappa \mathrm{B}$ activation [46-50].

5.2. Timing of AIRE Expression. AIRE expression is confined to a final stage of cell maturation, as shown in vitro and in vivo by the postmitotic status of murine Aire ${ }^{+}$mTECs $[51,52]$; in addition, Aire ${ }^{+}$mTECs show a very limited life span $[53,54]$. It is also indicative that $\mathrm{Aire}^{+}$mTECs, because of their degree of differentiation, are highly sensitive to the drug-mediated ablation of the thymic medulla, and that their regeneration follows an invariant pattern [55].

It has been suggested that AIRE expression, and consequently that of AIRE-dependent genes, are strategically delayed just to allow a full T-cell responsiveness [56].

5.3. Modulation of AIRE Expression. Currently, we do not know whether the level of AIRE expression is genetically set, and whether metabolic, or environmental, or other agents are able to modulate it. This phenomenon, if determining the amount of TsAgs encoded by AIRE-dependent genes, could influence the chances of the autoreactive T-cell clones to encounter their targets and impact the efficiency of negative selection.

Studies on Aire ${ }^{-/-}$mice showed that the thymic expression of the genes dependent on Aire is quantitatively related to the amount of it, and that, in heterozygous $\left(A i r e^{+/-}\right.$) mice, intermediate level of mRNAs condition the number of autoreactive T-cell clones escaping thymic deletion [57]. This led the researchers to suggest that, in human field, the condition of heterozygosity for pathogenic AIRE variants could confer a risk for the onset of sporadic autoimmune diseases, when acting in synergy with other susceptibility factors. Actually, no data support this hypothesis.
Chen et al. found that, in the murine thymus, baseline Aire expression is related to the genetic background, as mTECs of nonobese diabetic (NOD) mice displayed lower levels of mRNAs from Aire and three Aire-dependent TsAgencoding genes, when compared to mTECs of Balb/c mice [58]; Heino et al. had already found that Aire ${ }^{+}$mTECs of NOD mice show an abnormal morphology [28].

Later, Venanzi et al. demonstrated that, in nonautoimmune-prone C57BL/6 mice, Aire activates more strongly the transcription of TsAg-encoding genes, and that the same genes are more severely downregulated in Aire ${ }^{-/-}$ animals of the same strain. Unexpectedly, the percentage of Aire $^{+}$mTECs was higher in the thymus of NOD mice [59].

According to these findings, autoimmune-prone mice would show a less strict regulation of dependence on Aire, more than a deficient amount of it.

\section{Thymic Diseases and AIRE Expression in Human Field}

6.1. Severe Combined Immunodeficiency (SCID). Omenn syndrome is characterized by peripheral expansion of oligoclonal $\mathrm{T}$ lymphocytes with autoreactive propensity. Impairment in various steps of T-cell maturation may cause the disease: the most frequent defect is caused by pathogenic variants in the recombinase-activating genes 1 and 2 (RAG-1 and RAG-2, resp.) [60]. In all jawed vertebrates, RAG proteins induce a DNA rearrangement, called $\mathrm{V}(\mathrm{D}) \mathrm{J}$ recombination, that reassembles the exons encoding for the antigen-binding domains of TCRs from the native variable, diversity, and joining gene segments [61-63].

Some patients with Omenn syndrome and RAG deficiency have a marked decrease of circulating $\mathrm{T}$ and $\mathrm{B}$ lymphocytes, a condition referred to as $\mathrm{T}^{-} \mathrm{B}^{-} \mathrm{SCID}$ [64]. In either 
TABle 2: Aire expression (Aire mRNA and Aire protein) in murine extra-thymic systems, organs, and tissues.

\begin{tabular}{|c|c|c|c|c|}
\hline \multirow[b]{2}{*}{ Systems, organs, tissues } & \multicolumn{2}{|c|}{ Aire expression negative or negligibly positive } & \multicolumn{2}{|c|}{ Aire expression moderately or strongly positive } \\
\hline & Techniques & Cell types & Techniques & Cell types \\
\hline Bone marrow & & & $\begin{array}{l}\text { isH [29] } \\
\text { IHC [29] }\end{array}$ & $\begin{array}{l}\text { Myeloblasts [29] } \\
\text { Lymphoblasts [29] } \\
\text { Megacaryocytes [29] }\end{array}$ \\
\hline Lymph nodes & $\begin{array}{l}\text { WB }[28] \\
\mathrm{IHC}[28,29]\end{array}$ & $\begin{array}{l}\text { Lymphocytes } \\
\text { (germinal-center) [29] }\end{array}$ & $\begin{array}{l}\text { isH }[29] \\
\text { RT-PCR }[28-30] \\
\text { IHC }[29,32]\end{array}$ & $\begin{array}{l}\text { Lymphocytes (germinal-center) [32] } \\
\text { Lymphocytes (paracortical) [32] } \\
\text { Lymphocytes (medullary) [29] } \\
\text { DCs [29] }\end{array}$ \\
\hline Spleen & $\begin{array}{l}\text { NB [26, 27] } \\
\text { isH [32] } \\
\text { RT-PCR [27] } \\
\text { WB [28] } \\
\text { IHC }[28,29,32]\end{array}$ & $\begin{array}{l}\text { Lymphocytes (red-pulp) } \\
\text { [32] } \\
\text { Lymphocytes } \\
\text { (white-pulp) [29] }\end{array}$ & $\begin{array}{l}\text { isH [29] } \\
\text { RT-PCR [26, 28-32] } \\
\text { IHC [29, 32] } \\
\text { IF [32] }\end{array}$ & $\begin{array}{l}\text { Neutrophilic granulocytes [29] } \\
\text { Lymphocytes (red-pulp) [29] } \\
\text { Lymphocytes (white-pulp) [32] } \\
\text { B lymphocytes [32] } \\
\text { T lymphocytes [32] } \\
\text { DCs [29] } \\
\text { DCs (myeloid-lineage) [28, 31] } \\
\text { DCs (lymphoid-lineage) [28] } \\
\text { Macrophages [29] } \\
\text { Smooth-muscle cells [29] }\end{array}$ \\
\hline Fetal liver & & & RT-PCR [29] & \\
\hline Adult liver & $\begin{array}{l}\text { NB }[26,27] \\
\text { isH }[32] \\
\text { RT-PCR } \\
{[27,30]} \\
\text { WB }[28,32] \\
\text { IHC }[28,32]\end{array}$ & & $\begin{array}{l}\text { isH }[29] \\
\text { RT-PCR }[28,29,32] \\
\text { IHC }[29,34]\end{array}$ & $\begin{array}{l}\text { Hepatocytes }[29,34] \\
\text { Küpffer cells }[29]\end{array}$ \\
\hline Peripheral blood leukocytes & RT-PCR [28] & & ICC [29] & $\begin{array}{l}\text { Neutrophilic granulocytes [29] } \\
\text { PBLs [29] } \\
\text { Monocytes [29] }\end{array}$ \\
\hline Skeletal muscle & $\begin{array}{l}\text { NB }[26,27] \\
\text { WB }[28] \\
\text { IHC }[28]\end{array}$ & & RT-PCR $[26,28]$ & \\
\hline Heart & $\begin{array}{l}\text { NB }[26] \\
\text { isH }[32] \\
\text { RT-PCR } \\
{[27,30]} \\
\text { IHC }[32]\end{array}$ & & RT-PCR $[26,32]$ & \\
\hline $\begin{array}{l}\text { Respiratory system (upper } \\
\text { and lower tract) }\end{array}$ & $\begin{array}{l}\text { NB [26] } \\
\text { isH [32] } \\
\text { RT-PCR [30] } \\
\text { WB [28] } \\
\text { IHC }[28,32]\end{array}$ & $\begin{array}{l}\text { Small-airway epithelial } \\
\text { cells [32] } \\
\text { Alveolar cells [32] }\end{array}$ & $\begin{array}{l}\text { RT-PCR }[26,27,32] \\
\text { IHC }[29,32]\end{array}$ & $\begin{array}{l}\text { Airway epithelial cells [29] } \\
\text { Large-airway epithelial cells [32] } \\
\text { Type-1 and type-2 pneumocytes [29] } \\
\text { Alveolar macrophages [29] }\end{array}$ \\
\hline Salivary glands & RT-PCR [30] & & IHC [29] & Tubulo-acinar and duct cells [29] \\
\hline $\begin{array}{l}\text { Gastrointestinal system } \\
\text { (upper tract) }\end{array}$ & $\begin{array}{l}\text { NB [27] } \\
\text { isH [32] } \\
\text { RT-PCR [30] }\end{array}$ & & $\begin{array}{l}\text { RT-PCR [32] } \\
\text { IHC [29] }\end{array}$ & $\begin{array}{l}\text { Mucosal and glandular epithelial cells } \\
\text { [29] }\end{array}$ \\
\hline $\begin{array}{l}\text { Gastrointestinal system (small } \\
\text { intestine and large bowel) }\end{array}$ & $\begin{array}{l}\text { NB [27] } \\
\text { isH [32] } \\
\text { IHC [32] }\end{array}$ & $\begin{array}{l}\text { Enterocytes (small } \\
\text { intestine) [32] } \\
\text { Neuroendocrine cells } \\
{[32]}\end{array}$ & $\begin{array}{l}\text { RT-PCR }[32] \\
\text { IHC }[29,32]\end{array}$ & $\begin{array}{l}\text { Mucosal and glandular epithelial cells } \\
{[29]} \\
\text { Goblet cells [32] }\end{array}$ \\
\hline Hypophysis & & & IHC [29] & $\begin{array}{l}\text { Anterior- and intermediate-lobe cells } \\
\text { [29] }\end{array}$ \\
\hline Thyroid & $\begin{array}{l}\text { RT-PCR } \\
{[27,30]}\end{array}$ & & IHC [29] & Follicular and parafollicular cells [29] \\
\hline Pancreas & $\begin{array}{l}\text { RT-PCR } \\
{[27,28,30]}\end{array}$ & & IHC [29] & $\begin{array}{l}\text { Langerhans-islet cells [29] } \\
\text { Acinar cells [29] }\end{array}$ \\
\hline
\end{tabular}


TABle 2: Continued.

\begin{tabular}{|c|c|c|c|c|}
\hline \multirow[b]{2}{*}{ Systems, organs, tissues } & \multicolumn{2}{|c|}{ Aire expression negative or negligibly positive } & \multicolumn{2}{|c|}{ Aire expression moderately or strongly positive } \\
\hline & Techniques & Cell types & Techniques & Cell types \\
\hline Adrenal gland & $\begin{array}{l}\text { isH }[32] \\
\text { RT-PCR } \\
{[30,32]} \\
\text { WB }[28,32] \\
\text { IHC }[28,32]\end{array}$ & & $\begin{array}{l}\text { RT-PCR }[27,28] \\
\text { IHC [29] }\end{array}$ & $\begin{array}{l}\text { Cortical-layer cells [29] } \\
\text { Medullary chromaffin cells [29] }\end{array}$ \\
\hline Male genital system & $\begin{array}{l}\text { NB [26] } \\
\text { isH [32] } \\
\text { WB [28] } \\
\text { IHC }[28,32]\end{array}$ & $\begin{array}{l}\text { Mature germinal cells } \\
\text { [32] }\end{array}$ & $\begin{array}{l}\text { isH [29] } \\
\text { RT-PCR [26-29, 32] } \\
\text { IHC [29, 32] }\end{array}$ & $\begin{array}{l}\text { Germinal cells [29] } \\
\text { Immature germinal cells [32] } \\
\text { Sertoli cells [29] } \\
\text { Leydig cells [29] } \\
\text { Spermatic-tract epithelial cells [29] }\end{array}$ \\
\hline Female genital system & $\begin{array}{l}\text { isH [32] } \\
\mathrm{WB}[28] \\
\mathrm{IHC}[28]\end{array}$ & & $\begin{array}{l}\text { isH }[29] \\
\text { RT-PCR }[27,30,32] \\
\text { IHC }[29,32]\end{array}$ & $\begin{array}{l}\text { Oocytes [29] } \\
\text { Follicular cells [29, 32] } \\
\text { Luteal cells [29] } \\
\text { Interstitial cells [29] } \\
\text { Fallopian-tube epithelial cells [32] } \\
\text { Endometrial cells [29] } \\
\text { Myometrial cells [29] }\end{array}$ \\
\hline $\begin{array}{l}\text { Central and peripheral } \\
\text { nervous system }\end{array}$ & $\begin{array}{l}\text { NB [26] } \\
\text { isH [32] } \\
\text { RT-PCR [26] }\end{array}$ & & $\begin{array}{l}\text { isH }[29] \\
\text { RT-PCR }[29,32] \\
\text { IHC }[29,32,34]\end{array}$ & $\begin{array}{l}\text { Neurons of cerebral cortex, basal nuclei, } \\
\text { brainstem nuclei, spinal cord }[29,32] \\
\text { Granular neurons, Purkinje cells }[29,34 \\
\text { Glial cells [29] }\end{array}$ \\
\hline Eye and annexes & RT-PCR [30] & & IHC [29] & Retinal-layer elements [29] \\
\hline
\end{tabular}

Aire: autoimmune regulator, PBLs: peripheral blood lymphocytes, DCs: dendritic cells, NB: Northern blotting, isH: in situ hybridization, RT-PCR: reverse transcriptase-polymerase chain reaction, WB: Western blotting, IHC: immunohistochemistry, ICC: immunocytochemistry, and IF: immunofluorescence.

thymus or peripheral blood mononuclear cells (PBMCs) of patients suffering from these diseases, a substantial AIRE reduction was found [65-67]. In this sense, such forms of immunodeficiency, the classical SCID included, confirm the crucial role of AIRE in the mechanisms of central tolerance $[68,69]$.

A reasonable interpretation of what happens in these conditions leads to suppose that the thymi of the patients bearing genetically transmitted defects of the molecules involved in the developmental steps of $\mathrm{T}$ lymphocytes (with privileged reference to the construction of TCR diversity), show abnormalities of TEC differentiation, and consequently of AIRE expression, that are proportional to the timing of intervention of the same factors; hypomorphic variants of the related genes would result in more subtle disturbances [70-72].

6.2. Thymomas. Thymomas are rare tumors derived from TECs that are often associated with autoimmune diseases, mainly myasthenia gravis, caused by Abs to the acetylcholine receptor (AChR). It has been hypothesized that thymomaassociated AIRE deficiency may impair the tolerance to AChR and other antigens [73]. In facts although AIRE expression in thymomas is clearly decreased in terms of
AIRE mRNA and $\mathrm{AIRE}^{+}$cells, this datum does not correlate with the prevalence of myasthenia gravis $[74,75]$. Thymoma patients do not exhibit the typical picture of APS-1 [76], albeit with isolated exceptions [77], but some resemblances between thymoma-associated myasthenia gravis and APS-1 exist $[78,79]$.

An interesting point of contact between APS-1 and thymomas is the presence of circulating Abs to various cytokines, such as interferons (IFNs) and interleukins (ILs): in the original article of Meager et al., sera from APS-1 patients showed high-titer neutralizing Abs to type-1 IFNs such as IFN- $\alpha$, all subtypes included, and IFN- $\omega$; IFN- $\beta$, another member of type-1 IFNs, as well as IFN- $\lambda_{1}$, a subtype of type-3 IFNs, were less frequently targeted [80]. The same Abs were found in a large number of thymoma patients with myasthenia gravis, albeit the titer was significantly lower [80].

These findings led the authors to hypothesize that in abnormal thymic microenvironments made vulnerable by AIRE deficiency, the process of autoreactivity focuses early on molecules, such as type-1 IFNs, that result to be abundantly in loco available [81].

In a second time, Abs to the cytokines produced by Th17 subset of T-helper lymphocytes, namely IL-17A, IL-17F, and 
IL-22, were found in a high number of APS-1 patients; remarkably, the occurrence of such Abs in thymoma patients regarded mostly the restricted number of them that suffered from chronic mucocutaneous candidiasis, strengthening the similarities between the two diseases $[82,83]$.

In a further study, the same research group, utilizing a radioligand-binding assay, confirmed that Abs to IFN$\omega$ occur in the totality of APS-1 patients and beat the prevalence of Abs to two subtypes of IFN- $\alpha$, namely IFN- $\alpha_{2}$ and IFN- $\alpha_{8}$, that in turn are found in a high percentage of patients with thymoma-associated myasthenia gravis [84].

Leaving aside the autoimmune phenomena, the hypothesis that AIRE deficiency may contribute in thymomas to the tumor-promoting antiapoptotic features of TECs should not be discharged [85].

6.3. Down Syndrome. Down syndrome is characterized by thymic atrophy, and a decrease in $\mathrm{AIRE}^{+}$cells was found in the thymus of subjects with Down syndrome who had undergone surgical thymectomy because of congenital heart malformations [86]. These data seem to deny that susceptibility to autoimmunity in Down syndrome would be a consequence of the precocious ageing.

\section{Thymic Diseases and Aire Expression in Animal Models}

7.1. Experimental Blocks in Thymocyte Maturation. Engineering animal models in which thymic organogenesis is disturbed provide a relevant contribution to the comprehension of the phenomena observed in the corresponding human diseases. A strategic choice is the block, at various stages of the process, of the thymocyte maturation, with the study of the related consequences on the architecture of the thymus in its entirety, and on the developmental steps of TECs: Tge26 and Rag-deficient $\left(\mathrm{Rag}^{-/-}\right)$mice are examples of animal models utilized in such studies.

Tge26 mouse expresses a high number of the invariant CD3- $\varepsilon$ chain belonging to TCR complex, and its thymocytes are blocked at DN1-DN2 stages, where DN stays for double-negative and indicates a $\mathrm{CD} 4{ }^{-} \mathrm{CD} 8^{-}$condition, with subdivision based on the progressive expression of CD44 and CD25. $\mathrm{Rag}^{-/-}$mouse recalls the most frequent defect causing Omenn syndrome: as reported, RAG/Rag proteins are indispensable to create TCR diversity and an adequate T-cell repertoire; the consequence of their deficiency is an impaired thymocyte maturation, with a block at DN3 stage [87].

A prototypical study in this field was that of Zuklys et al.: as seen above, Aire mRNA and Aire protein are recovered in murine embryos at 14-14.5 days after conception, slightly anticipating DN3 stage of thymocyte maturation. Consistently with these data, the authors found that thymi from Tge 26 mice lacked an orthodox three-dimensional TEC network, and Aire mRNA could not be detected; conversely, the block of thymopoiesis in $R a g-2^{-/-}$mice altered only partially the thymic compartmentalization, and the related mTEC differentiation and Aire expression [88].
As well as in human field, following studies suggest that the degree of thymic abnormalities, Aire expression included, depends on how precociously the factors damaged by pathogenic variants of the encoding genes act in the construction of TCR diversity [89-92].

7.2. Experimental Defects in NF- $\kappa B$ Signal-Transduction Pathways. Several studies have taken in account various murine constitutional and experimentally induced defects involving the molecules that participate to the signal-transduction pathways enabling NFs- $\kappa \mathrm{B}$, to elucidate the impact of each step impairment on mTEC properties, with particular regard to Aire expression [28, 88, 93-117]. A detailed report of such articles goes beyond the scope of the present work, but, as indicated, excellent reviews are available [46-50].

7.3. Other Experimental Diseases Targeting the Thymus. Also protozoan infections, such as that from Trypanosoma cruzi, target the thymus and are able to cause its atrophy: Morrot et al. studied a murine model of Chagas disease and found that thymic expression of Aire and TsAg-encoding genes was preserved, albeit this condition was accompanied by early release of activated $\mathrm{T}$ lymphocytes into the periphery [118].

\section{Conclusions and Future Remarks}

It is definitively proven that the highest level of AIRE expression, as well as that of its murine homolog, is seen in a subset of mTECs. The low-level transcription in thymic DCs is presumably finalized to increase the availability of TsAgs to be presented to the autoreactive T-cell clones.

The detection of AIRE mRNA in nonlymphoid organs remains questionable and could be due to the presence, in bulk tissue samples, of few AIRE-expressing cells (for example, elements of the monocyte/DC lineage) ordinarily inhabiting the organs, or contaminating the preparations. However, a barely detectable AIRE mRNA does not imply appreciable levels of translation.

In searching for AIRE protein, greater accuracy comes from the use of monoclonal anti-AIRE Abs, especially if joined to methods, such as flow cytometry, able to improve the purity of the cell samples.

In any case, thymic localization of AIRE remains the most relevant to its function: a confirmation of the hypothesis that, by modulating thymic AIRE expression, we would be able to condition the susceptibility to autoimmune diseases, could delineate promising opportunities in the fight against autoimmunity. There is growing evidence that, as suggested by animal models, secondary lymphoid organs (lymph nodes and spleen) repropose in the periphery the mechanisms of central tolerance. This phenomenon needs better characterization, starting from the most accurate definition of AIRE and TsAg-encoding gene expression in the stromal cell lineages of the involved organs.

\section{Conflict of Interests}

The author declares that he has no conflict of interests. 


\section{Acknowledgment}

The author wishes to thank Dr. Stefano Quarta, Department of Medical Physics, V. Fazzi Regional Hospital, Lecce, for his technical assistance.

\section{References}

[1] C. Betterle, N. A. Greggio, and M. Volpato, "Autoimmune polyglandular syndrome type 1," Journal of Clinical Endocrinology and Metabolism, vol. 83, no. 4, pp. 1049-1055, 1998.

[2] J. Perheentupa, "Autoimmune polyendocrinopathy-candidiasis-ectodermal dystrophy," Journal of Clinical Endocrinology and Metabolism, vol. 91, no. 8, pp. 2843-2850, 2006.

[3] J. Aaltonen, P. Bjorses, L. Sandkuijl, J. Perheentupa, and L. Peltonen, "An autosomal locus causing autoimmune disease: autoimmune polyglandular disease type I assigned to chromosome 21," Nature Genetics, vol. 8, no. 1, pp. 83-87, 1994.

[4] K. Nagamine, P. Peterson, H. S. Scott et al., "Positional cloning of the APECED gene," Nature Genetics, vol. 17, no. 4, pp. 393-398, 1997.

[5] J. Aaltonen, P. Björses, J. Perheentupa et al., "An autoimmune disease, APECED, caused by mutations in a novel gene featuring two PHD-type zinc-finger domains," Nature Genetics, vol. 17, no. 4, pp. 399-403, 1997.

[6] P. Björses, J. Aaltonen, N. Horelli-Kuitunen, M. L. Yaspo, and L. Peltonen, "Gene defect behind APECED: a new clue to autoimmunity," Human Molecular Genetics, vol. 7, no. 10, pp. 1547-1553, 1998.

[7] P. Peterson, K. Nagamine, H. Scott et al., "APECED: a monogenic autoimmune disease providing new clues to selftolerance," Immunology Today, vol. 19, no. 9, pp. 384-386, 1998.

[8] D. Mathis and C. Benoist, "Aire," Annual Review of Immunology, vol. 27, pp. 287-312, 2009.

[9] R. T. Taniguchi and M. S. Anderson, "The role of Aire in clonal selection," Immunology and Cell Biology, vol. 89, no. 1, pp. 40-44, 2011.

[10] M. Heino, P. Peterson, J. Kudoh et al., "Autoimmune regulator is expressed in the cells regulating immune tolerance in thymus medulla," Biochemical and Biophysical Research Communications, vol. 257, no. 3, pp. 821-825, 1999.

[11] P. Björses, M. Pelto-Huikko, J. Kaukonen, J. Aaltonen, L. Peltonen, and I. Ulmanen, "Localization of the APECED protein in distinct nuclear structures," Human Molecular Genetics, vol. 8, no. 2, pp. 259-266, 1999.

[12] C. Rinderle, H. M. Christensen, S. Schweiger, H. Lehrach, and M. L. Yaspo, "AIRE encodes a nuclear protein co-localizing with cytoskeletal filaments: altered sub-cellular distribution of mutants lacking the PHD zinc fingers," Human Molecular Genetics, vol. 8, no. 2, pp. 277-290, 1999.

[13] K. Kogawa, S. Nagafuchi, H. Katsuta et al., "Expression of AIRE gene in peripheral monocyte/dendritic cell lineage," Immunology Letters, vol. 80, no. 3, pp. 195-198, 2002.

[14] N. Sillanpää, C. G. Magureanu, A. Murumägi et al., "Autoimmune regulator induced changes in the gene expression profile of human monocyte-dendritic cell-lineage," Molecular Immunology, vol. 41, no. 12, pp. 1185-1198, 2004.

[15] N. Pöntynen, M. Strengell, N. Sillanpää et al., "Critical immunological pathways are downregulated in APECED patient dendritic cells," Journal of Molecular Medicine, vol. 86, no. 10, pp. 1139-1152, 2008.
[16] T. Klamp, U. Sahin, B. Kyewski, J. Schwendemann, K. Dhaene, and Ö. Türeci, "Expression profiling of autoimmune regulator AIRE mRNA in a comprehensive set of human normal and neoplastic tissues," Immunology Letters, vol. 106, no. 2, pp. 172-179, 2006.

[17] S. Nagafuchi, H. Katsuta, Y. Ohno et al., "Mitogenactivated protein kinase pathway controls autoimmune regulator (AIRE) gene expression in granulo-monocyte colony stimulating factor (GM-CSF)-stimulated myelomonocytic leukemia OTC-4 cells," Immunology Letters, vol. 99, no. 1, pp. 130-135, 2005.

[18] P. L. Poliani, K. Kisand, V. Marrella et al., "Human peripheral lymphoid tissues contain autoimmune regulator-expressing dendritic cells," American Journal of Pathology, vol. 176, no. 3, pp. 1104-1112, 2010.

[19] S. Nagafuchi, H. Katsuta, R. Koyanagi-Katsuta et al., "Autoimmune regulator (AIRE) gene is expressed in human activated $\mathrm{CD}^{+}$T-cells and regulated by mitogen-activated protein kinase pathway," Microbiology and Immunology, vol. 50, no. 12, pp. 979-987, 2006.

[20] E. Suzuki, Y. Kobayashi, O. Kawano et al., "Expression of AIRE in thymocytes and peripheral lymphocytes," Autoimmunity, vol. 41, no. 2, pp. 133-139, 2008.

[21] M. Harris, O. Kecha, C. Deal et al., "Reversible metaphyseal dysplasia, a novel bone phenotype, in two unrelated children with autoimmunepolyendocrinopathy-candidiasisectodermal dystrophy: clinical and molecular studies," Journal of Clinical Endocrinology and Metabolism, vol. 88, no. 10, pp. 4576-4585, 2003.

[22] S. K. Uppalapati, M. Bertolini, K. C. Meyer, S. Tiede, P. Peterson, and R. Paus, "Gene and protein expression of AIRE (Autoimmune Regulator) in alopecia areata compared to normal human scalp skin," Experimental Dermatology, vol. 19, no. 2, p. 191, 2010.

[23] V. Kumar, L. A. Pedroza, E. M. Mace et al., "The Autoimmune Regulator (AIRE), which is defective in autoimmune polyendocrinopathy-candidiasis-ectodermal dystrophy patients, is expressed in human epidermal and follicular keratinocytes and associates with the intermediate filament protein cytokeratin 17," American Journal of Pathology, vol. 178, no. 3, pp. 983-988, 2011.

[24] R. A. Clark, K. I. Yamanaka, M. Bai, R. Dowgiert, and T. S. Kupper, "Human skin cells support thymus-independent T cell development," Journal of Clinical Investigation, vol. 115, no. 11, pp. 3239-3249, 2005.

[25] L. Mittaz, C. Rossier, M. Heino et al., "Isolation and characterization of the mouse Aire gene," Biochemical and Biophysical Research Communications, vol. 255, no. 2, pp. 483-490, 1999.

[26] K. Blechschmidt, M. Schweiger, K. Wertz et al., "The mouse Aire gene: comparative genomic sequencing, gene organization, and expression," Genome Research, vol. 9, no. 2, pp. 158-166, 1999.

[27] Q. G. Ruan, C. Y. Wang, J. D. Shi, and J. X. She, "Expression and alternative splicing of the mouse autoimmune regulator gene (Aire)," Journal of Autoimmunity, vol. 13, no. 3, pp. 307313, 1999.

[28] M. Heino, P. Peterson, N. Sillanpää et al., "RNA and protein expression of the murine autoimmune regulator gene (Aire) in normal, RelB-deficient and in NOD mouse," European Journal of Immunology, vol. 30, no. 7, pp. 1884-1893, 2000.

[29] M. Halonen, M. Pelto-Huikko, P. Eskelin, L. Peltonen, I. Ulmanen, and M. Kolmer, "Subcellular location and expression pattern of autoimmune regulator (Aire), the mouse 
orthologue for human gene defective in autoimmune polyendocrinopathy candidiasis ectodermal dystrophy (APECED)," Journal of Histochemistry and Cytochemistry, vol. 49, no. 2, pp. 197-208, 2001.

[30] M. S. Anderson, E. S. Venanzi, L. Klein et al., "Projection of an immunological self shadow within the thymus by the aire protein," Science, vol. 298, no. 5597, pp. 1395-1401, 2002.

[31] X. Zheng, L. Yin, Y. Liu, and P. Zheng, "Expression of tissue-specific autoantigens in the hematopoietic cells leads to activation-induced cell death of autoreactive $\mathrm{T}$ cells in the secondary lymphoid organs," European Journal of Immunology, vol. 34, no. 11, pp. 3126-3134, 2004.

[32] K. A. Adamson, S. H. S. Pearce, J. R. Lamb, J. R. Seckl, and S. E. M. Howie, "A comparative study of mRNA and protein expression of the autoimmune regulator gene (Aire) in embryonic and adult murine tissues," Journal of Pathology, vol. 202, no. 2, pp. 180-187, 2004.

[33] I. Hansenne, C. Louis, H. Martens et al., "Aire and Foxp3 expression in a particular microenvironment for $\mathrm{T}$ cell differentiation," NeuroImmunoModulation, vol. 16, no. 1, pp. 35-44, 2009.

[34] C. Ramsey, O. Winqvist, L. Puhakka et al., "Aire deficient mice develop multiple features of APECED phenotype and show altered immune response," Human Molecular Genetics, vol. 11, no. 4, pp. 397-409, 2002.

[35] F. X. Hubert, S. A. Kinkel, K. E. Webster et al., "A specific antiaire antibody reveals aire expression is restricted to medullary thymic epithelial cells and not expressed in periphery," Journal of Immunology, vol. 180, no. 6, pp. 3824-3832, 2008.

[36] J. W. Lee, M. Epardaud, J. Sun et al., "Peripheral antigen display by lymph node stroma promotes $\mathrm{T}$ cell tolerance to intestinal self," Nature Immunology, vol. 8, no. 2, pp. 181-190, 2007.

[37] J. M. Gardner, J. J. DeVoss, R. S. Friedman et al., "Deletional tolerance mediated by extrathymic aire-expressing cells," Science, vol. 321, no. 5890, pp. 843-847, 2008.

[38] V. Kont, M. Laan, K. Kisand, A. Merits, H. S. Scott, and P. Peterson, "Modulation of Aire regulates the expression of tissue-restricted antigens," Molecular Immunology, vol. 45, no. 1, pp. 25-33, 2008.

[39] J. N. Cohen, C. J. Guidi, E. F. Tewalt et al., "Lymph node-resident lymphatic endothelial cells mediate peripheral tolerance via Aire-independent direct antigen presentation," Journal of Experimental Medicine, vol. 207, no. 4, pp. 681$688,2010$.

[40] A. L. Fletcher, V. Lukacs-Kornek, E. D. Reynoso et al., "Lymph node fibroblastic reticular cells directly present peripheral tissue antigen under steady-state and inflammatory conditions," Journal of Experimental Medicine, vol. 207, no. 4, pp. 689-697, 2010.

[41] J. M. Gardner, A. L. Fletcher, M. S. Anderson, and S. J. Turley, "AIRE in the thymus and beyond," Current Opinion in Immunology, vol. 21, no. 6, pp. 582-589, 2009.

[42] A. L. Fletcher, D. Malhotra, and S. J. Turley, "Lymph node stroma broaden the peripheral tolerance paradigm," Trends in Immunology, vol. 32, no. 1, pp. 12-18, 2011.

[43] C. E. Schaller, C. L. Wang, G. Beck-Engeser et al., "Expression of Aire and the early wave of apoptosis in spermatogenesis," Journal of Immunology, vol. 180, no. 3, pp. 1338-1343, 2008.

[44] S. A. Eldershaw, D. M. Sansom, and P. Narendran, "Expression and function of the autoimmune regulator (Aire) gene in non-thymic tissue," Clinical and Experimental Immunology, vol. 163, no. 3, pp. 296-308, 2011.
[45] M. S. Hayden and S. Ghosh, "NF- $\kappa$ B, the first quartercentury: remarkable progress and outstanding questions," Genes and Development, vol. 26, no. 3, pp. 203-234, 2012.

[46] J. Derbinski and B. Kyewski, "Linking signalling pathways, thymic stroma integrity and autoimmunity," Trends in Immunology, vol. 26, no. 10, pp. 503-506, 2005.

[47] L. O. Tykocinski, A. Sinemus, and B. Kyewski, "The thymus medulla slowly yields its secrets," Annals of the New York Academy of Sciences, vol. 1143, pp. 105-122, 2008.

[48] M. Irla, G. Hollander, and W. Reith, "Control of central self-tolerance induction by autoreactive $\mathrm{CD} 4^{+}$thymocytes," Trends in Immunology, vol. 31, no. 2, pp. 71-79, 2010.

[49] M. Zhu, N. K. Brown, and Y. X. Fu, "Direct and indirect roles of the LT $\beta$ R pathway in central tolerance induction," Trends in Immunology, vol. 31, no. 9, pp. 325-331, 2010.

[50] T. Nitta, I. Ohigashi, Y. Nakagawa, and Y. Takahama, "Cytokine crosstalk for thymic medulla formation," Current Opinion in Immunology, vol. 23, no. 2, pp. 190-197, 2011.

[51] B. Kyewski and J. Derbinski, "Self-representation in the thymus: an extended view," Nature Reviews Immunology, vol. 4, no. 9, pp. 688-698, 2004.

[52] B. Kyewski and L. Klein, "A central role for central tolerance," Annual Review of Immunology, vol. 24, pp. 571-606, 2006.

[53] R. Sousa Cardoso, D. A. R. Magalhães, A. M. T. Baião et al., "Onset of promiscuous gene expression in murine fetal thymus organ culture," Immunology, vol. 119, no. 3, pp. 369375, 2006.

[54] D. Gray, J. Abramson, C. Benoist, and D. Mathis, "Proliferative arrest and rapid turnover of thymic epithelial cells expressing Aire," Journal of Experimental Medicine, vol. 204, no. 11, pp. 2521-2528, 2007.

[55] A. L. Fletcher, T. E. Lowen, S. Sakkal et al., "Ablation and regeneration of tolerance-inducing medullary thymic epithelial cells after cyclosporine, cyclophosphamide, and dexamethasone treatment," Journal of Immunology, vol. 183, no. 2, pp. 823-831, 2009.

[56] M. Cohn, "Why Aire? Compensating for late bloomers," European Journal of Immunology, vol. 39, no. 11, pp. 29692972, 2009.

[57] A. Liston, D. H. D. Gray, S. Lesage et al., "Gene dosagelimiting role of Aire in thymic expression, clonal deletion, and organ-specific autoimmunity," Journal of Experimental Medicine, vol. 200, no. 8, pp. 1015-1026, 2004.

[58] J. Chen, W. Yang, C. Yu, and Y. Li, "Autoimmune regulator initiates the expression of promiscuous genes in thymic epithelial cells," Immunological Investigations, vol. 37, no. 3, pp. 203-214, 2008.

[59] E. S. Venanzi, R. Melamed, D. Mathis, and C. Benoist, "The variable immunological self: genetic variation and nongenetic noise in Aire-regulated transcription," Proceedings of the National Academy of Sciences of the United States of America, vol. 105, no. 41, pp. 15860-15865, 2008.

[60] M. Van Der Burg and A. R. Gennery, "The expanding clinical and immunological spectrum of severe combined immunodeficiency," European Journal of Pediatrics, vol. 170, no. 5, pp. 561-571, 2011.

[61] M. Sadofsky, "The RAG proteins in V(D)J recombination: more than just a nuclease," Nucleic Acids Research, vol. 29, no. 7, pp. 1399-1409, 2001.

[62] P. C. Swanson, S. Kumar, and P. Raval, "Early steps of V(D)J rearrangement: insights from biochemical studies of RAGRSS complexes," Advances in Experimental Medicine and Biology, vol. 650, pp. 1-15, 2009. 
[63] E. Hsu, "V(D)J recombination: of mice and sharks," Advances in Experimental Medicine and Biology, vol. 650, pp. 166-179, 2009.

[64] L. D. Notarangelo, A. Fischer, R. S. Geha et al., "Primary immunodeficiencies: 2009 update," Journal of Allergy and Clinical Immunology, vol. 124, no. 6, pp. 1161-1178, 2009.

[65] P. Cavadini, W. Vermi, F. Facchetti et al., "AIRE deficiency in thymus of 2 patients with Omenn syndrome," Journal of Clinical Investigation, vol. 115, no. 3, pp. 728-732, 2005.

[66] R. Somech, A. J. Simon, A. Lev et al., "Reduced central tolerance in Omenn syndrome leads to immature selfreactive oligoclonal T cells," Journal of Allergy and Clinical Immunology, vol. 124, no. 4, pp. 793-800, 2009.

[67] S. S. De Ravin, E. W. Cowen, K. A. Zarember et al., "Hypomorphic Rag mutations can cause destructive midline granulomatous disease," Blood, vol. 116, no. 8, pp. 1263 1271, 2010.

[68] L. S. Westerberg, C. Klein, and S. B. Snapper, "Breakdown of $\mathrm{T}$ cell tolerance and autoimmunity in primary immunodeficiency-lessons learned from monogenic disorders in mice and men," Current Opinion in Immunology, vol. 20, no. 6, pp. 646-654, 2008.

[69] J. D. Milner, A. Fasth, and A. Etzioni, "Autoimmunity in severe combined immunodeficiency (SCID): lessons from patients and experimental models," Journal of Clinical Immunology, vol. 28, no. 1, supplement, pp. S29-S33, 2008.

[70] L. D. Notarangelo, L. Poliani, M. Ravanini, F. Facchetti, A. Villa, and C. M. Roifman, "Impact of early and late human T-cell development defects on maturation of thymic epithelium: relevance to the pathophysiology of Omenn syndrome and leaky SCID," Clinical and Experimental Immunology, vol. 154, no. 1, supplement, pp. 7-8, 2008.

[71] P. L. Poliani, F. Facchetti, M. Ravanini et al., "Early defects in human T-cell development severely affect distribution and maturation of thymic stromal cells: possible implications for the pathophysiology of Omenn syndrome," Blood, vol. 114, no. 1, pp. 105-108, 2009.

[72] P. L. Poliani, W. Vermi, and F. Facchetti, "Thymus microenvironment in human primary immunodeficiency diseases," Current Opinion in Allergy and Clinical Immunology, vol. 9, no. 6, pp. 489-495, 2009.

[73] G. J. Offerhaus, M. E. I. Schipper, A. J. Lazenby et al., "Graftversus-host-like disease complicating thymoma: lack of AIRE expression as a cause of non-hereditary autoimmunity?" Immunology Letters, vol. 114, no. 1, pp. 31-37, 2007.

[74] S. Scarpino, A. Di Napoli, A. Stoppacciaro et al., "Expression of autoimmune regulator gene (AIRE) and T regulatory cells in human thymomas," Clinical and Experimental Immunology, vol. 149, no. 3, pp. 504-512, 2007.

[75] E. Suzuki, Y. Kobayashi, M. Yano, and Y. Fujii, "Infrequent and low AIRE expression in thymoma: difference in AIRE expression among WHO subtypes does not correlate with association of MG," Autoimmunity, vol. 41, no. 5, pp. 377382, 2008.

[76] P. Ströbel, A. Murumägi, R. Klein et al., "Deficiency of the autoim-mune regulator AIRE in thymomas is insufficient to elicit autoimmune polyendocrinopathy syndrome type 1 (APS-1)," Journal of Pathology, vol. 211, no. 5, pp. 563-571, 2007.

[77] M. H. Cheng, U. Fan, N. Grewal et al., "Acquired autoimmune polyglandular syndrome, thymoma, and an AIRE defect," New England Journal of Medicine, vol. 362, no. 8, pp. 764-766, 2010.
[78] P. Ströbel, W. Y. Chuang, S. Chuvpilo et al., "Common cellular and diverse genetic basis of thymoma-associated myasthenia gravis: role of MHC class II and AIRE genes and genetic polymorphisms," Annals of the New York Academy of Sciences, vol. 1132, pp. 143-156, 2008.

[79] A. Marx, N. Willcox, M. I. Leite et al., "Thymoma and paraneoplastic myasthenia gravis," Autoimmunity, vol. 43, no. 5-6, pp. 413-427, 2010.

[80] A. Meager, K. Visvalingam, P. Peterson et al., "Anti-interferon autoantibodies in autoimmune polyendocrinopathy syndrome type 1," PLoS Medicine, vol. 3, no. 7, pp. 1152-1164, 2006.

[81] A. Meager, P. Peterson, and N. Willcox, "Hypothetical review: thymic aberrations and type-I interferons; attempts to deduce autoimmunizing mechanisms from unexpected clues in monogenic and paraneoplastic syndromes," Clinical and Experimental Immunology, vol. 154, no. 1, pp. 141-151, 2008.

[82] K. Kisand, A. S. Bøe Wolff, K. T. Podkrajšek et al., "Chronic mucocutaneous candidiasis in APECED or thymoma patients correlates with autoimmunity to Th17-associated cytokines," Journal of Experimental Medicine, vol. 207, no. 2, pp. 299-308, 2010.

[83] K. Kisand, D. Lilic, J. L. Casanova, P. Peterson, A. Meager, and N. Willcox, "Mucocutaneous candidiasis and autoimmunity against cytokines in APECED and thymoma patients: clinical and pathogenetic implications," European Journal of Immunology, vol. 41, no. 6, pp. 1517-1527, 2011.

[84] L. Hapnes, N. Willcox, B. E. V. Oftedal et al., "Radioligandbinding assay reveals distinct autoantibody preferences for type I interferons in APS I and myasthenia gravis subgroups," Journal of Clinical Immunology, vol. 32, no. 2, pp. 230-237, 2012.

[85] A. Marx, P. Hohenberger, H. Hoffmann et al., "The autoimmune regulator AIRE in thymoma biology: autoimmunity and beyond," Journal of Thoracic Oncology, vol. 5, no. 10, pp. S266-S272, 2010.

[86] F. A. Lima, C. A. Moreira-Filho, and P. L. Ramos, "Decreased AIRE expression and global thymic hypofunction in Down syndrome," Journal of Immunology, vol. 187, no. 6, pp. 34223430, 2011.

[87] W. Van Ewijk, G. Holländer, C. Terhorst, and B. Wang, "Stepwise development of thymic microenvironments in vivo is regulated by thymocyte subsets," Development, vol. 127, no. 8, pp. 1583-1591, 2000.

[88] S. Zuklys, G. Balciunaite, A. Agarwal, E. Fasler-Kan, E. Palmer, and G. A. Hollander, "Normal thymic architecture and negative selection are associated with Aire expression, the gene defective in the autoimmune-polyendocrinopathycandidiasis-ectodermal dystrophy (APECED)," Journal of Immunology, vol. 165, no. 4, pp. 1976-1983, 2000.

[89] V. Marrella, P. L. Poliani, A. Casati et al., "A hypomorphic R229Q Rag2 mouse mutant recapitulates human Omenn syndrome," Journal of Clinical Investigation, vol. 117, no. 5, pp. 1260-1269, 2007.

[90] V. Marrella, A. Casati, and P. L. Poliani, "Impact of thymic epithelium on immunopathology in lymphopenic mice reconstituted with hypomorphic Rag2 haemopoietic progenitors," Clinical and Experimental Immunology, vol. 154, no. 1, supplement, pp. 6-7, 2008.

[91] L. D. Notarangelo, F. Rucci, and V. Marrella, "Hypomorphic $\mathrm{V}(\mathrm{D}) \mathrm{J}$ recombination mouse mutants have a different impact on thymic mechanisms of deletional and non-deletional central tolerance: implications for Omenn syndrome and 
leaky SCID," Clinical and Experimental Immunology, vol. 154, no. 1, supplement, p. 7, 2008.

[92] F. Rucci, P. L. Poliani, S. Caraffi et al., "Abnormalities of thymic stroma may contribute to immune dysregulation in murine models of leaky severe combined immunodeficiency," Frontiers in Immunology, vol. 2, Article ID e00015, 2011.

[93] T. Boehm, S. Scheu, K. Pfeffer, and C. C. Bleul, "Thymic medullary epithelial cell differentiation, thymocyte emigration, and the control of autoimmunity require lympho-epithelial cross talk via LT $\beta$ R," Journal of Experimental Medicine, vol. 198, no. 5, pp. 757-769, 2003.

[94] R. K. Chin, J. C. Lo, O. Kim et al., "Lymphotoxin pathway directs thymic Aire expression," Nature Immunology, vol. 4, no. 11, pp. 1121-1127, 2003.

[95] F. Kajiura, S. Sun, T. Nomura et al., "NF- $\kappa$ B-inducing kinase establishes self-tolerance in a thymic stroma-dependent manner," Journal of Immunology, vol. 172, no. 4, pp. 20672075, 2004.

[96] T. Akiyama, S. Maeda, S. Yamane et al., "Dependence of self-tolerance on TRAF6-directed development of thymic stroma," Science, vol. 308, no. 5719, pp. 248-251, 2005.

[97] M. O. Palumbo, D. Levi, A. A. Chentoufi, and C. Polychronakos, "Isolation and characterization of proinsulinproducing medullary thymic epithelial cell clones," Diabetes, vol. 55, no. 9, pp. 2595-2601, 2006.

[98] B. Zhang, Z. Wang, J. Ding, P. Peterson, W. T. Gunning, and H. F. Ding, "NF- $\kappa$ B2 is required for the control of autoimmunity by regulating the development of medullary thymic epithelial cells," Journal of Biological Chemistry, vol. 281, no. 50, pp. 38617-38624, 2006.

[99] M. Zhu, R. K. Chin, P. A. Christiansen et al., "NF- $\kappa$ B2 is required for the establishment of central tolerance through an Aire-dependent pathway," Journal of Clinical Investigation, vol. 116, no. 11, pp. 2964-2971, 2006.

[100] D. Kinoshita, F. Hirota, T. Kaisho et al., "Essential role of $\mathrm{I} \kappa \mathrm{B}$ kinase $\alpha$ in thymic organogenesis required for the establishment of self-tolerance," Journal of Immunology, vol. 176, no. 7, pp. 3995-4002, 2006.

[101] R. K. Chin, M. Zhu, P. A. Christiansen et al., "Lymphotoxin pathway-directed, autoimmune regulator-independent central tolerance to arthritogenic collagen," Journal of Immunology, vol. 177, no. 1, pp. 290-297, 2006.

[102] S. W. Rossi, M. Y. Kim, A. Leibbrandt et al., "RANK signals from $\mathrm{CD}^{+} 3^{-}$inducer cells regulate development of Aireexpressing epithelial cells in the thymic medulla," Journal of Experimental Medicine, vol. 204, no. 6, pp. 1267-1272, 2007.

[103] D. Lomada, B. Lin, L. Coghlan, Y. Hu, and E. R. Richie, "Thymus medulla formation and central tolerance are restored in IKK $\alpha^{-/-}$mice that express an IKK $\alpha$ transgene in keratin 5+ thymic epithelial cells," Journal of Immunology, vol. 178, no. 2, pp. 829-837, 2007.

[104] E. S. Venanzi, D. H. D. Gray, C. Benoist, and D. Mathis, "Lymphotoxin pathway and aire influences on thymic medullary epithelial cells are unconnected," Journal of Immunology, vol. 179, no. 9, pp. 5693-5700, 2007.

[105] M. Zhu, R. K. Chin, A. V. Tumanov, X. Liu, and Y. X. Fu, "Lymphotoxin $\beta$ receptor is required for the migration and selection of autoreactive T cells in thymic medulla," Journal of Immunology, vol. 179, no. 12, pp. 8069-8075, 2007.

[106] A. J. White, D. R. Withers, S. M. Parnell et al., "Sequential phases in the development of Aire-expressing medullary thymic epithelial cells involve distinct cellular input," European Journal of Immunology, vol. 38, no. 4, pp. 942-947, 2008.
[107] M. Zhu and Y. X. Fu, "Coordinating development of medullary thymic epithelial cells," Immunity, vol. 29, no. 3, pp. 386-388, 2008.

[108] T. Akiyama, Y. Shimo, H. Yanai et al., "The tumor necrosis factor family receptors RANK and CD40 cooperatively establish the thymic medullary microenvironment and selftolerance," Immunity, vol. 29, no. 3, pp. 423-437, 2008.

[109] Y. Hikosaka, T. Nitta, I. Ohigashi et al., "The cytokine RANKL produced by positively selected thymocytes fosters medullary thymic epithelial cells that express autoimmune regulator," Immunity, vol. 29, no. 3, pp. 438-450, 2008.

[110] M. Irla, S. Hugues, J. Gill et al., "Autoantigen-specific interactions with $\mathrm{CD}^{+}$thymocytes control mature medullary thymic epithelial cell cellularity," Immunity, vol. 29, no. 3, pp. 451-463, 2008.

[111] N. Seach, T. Ueno, A. L. Fletcher et al., "The lymphotoxin pathway regulates aire-independent expression of ectopic genes and chemokines in thymic stromal cells," Journal of Immunology, vol. 180, no. 8, pp. 5384-5392, 2008.

[112] V. C. Martins, T. Boehm, and C. C. Bleul, "Lt $\beta$ r signaling does not regulate Aire-dependent transcripts in medullary thymic epithelial cells," Journal of Immunology, vol. 181, no. 1, pp. 400-407, 2008.

[113] A. L. Fletcher, N. Seach, J. J. Reiseger et al., "Reduced thymic aire expression and abnormal NF- $\kappa \mathrm{B} 2$ signaling in a model of systemic autoimmunity," Journal of Immunology, vol. 182, no. 5, pp. 2690-2699, 2009.

[114] M. Saade, M. Irla, M. Yammine et al., "Spatial (Tbata) expression in mature medullary thymic epithelial cells," European Journal of Immunology, vol. 40, no. 2, pp. 530-538, 2010.

[115] N. M. Danzl, L. T. Donlin, and K. Alexandropoulos, "Regulation of medullary thymic epithelial cell differentiation and function by the signaling protein Sin," Journal of Experimental Medicine, vol. 207, no. 5, pp. 999-1013, 2010.

[116] I. Ohigashi, T. Nitta, E. Lkhagvasuren, H. Yasuda, and Y. Takahama, "Effects of RANKL on the thymic medulla," European Journal of Immunology, vol. 41, no. 7, pp. 18221827, 2011.

[117] N. A. Roberts, A. J. White, and W. E. Jenkinson, "Rank signaling links the development of invariant $\gamma \delta \mathrm{T}$ cell progenitors and Aire $^{+}$medullary epithelium," Immunity, vol. 36, no. 3, pp. 427-437, 2012.

[118] A. Morrot, E. Terra-Granado, and A. R. Pérez, "Chagasic thymic atrophy does not affect negative selection but results in the export of activated $\mathrm{CD} 4^{+} \mathrm{CD} 8^{+} \mathrm{T}$ cells in severe forms of human disease," PLoS Neglected Tropical Diseases, vol. 5, no. 8, Article ID e1268, 2011. 


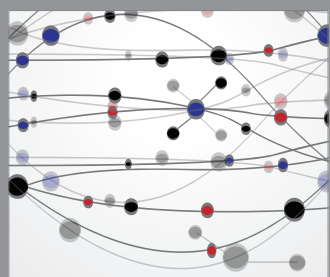

The Scientific World Journal
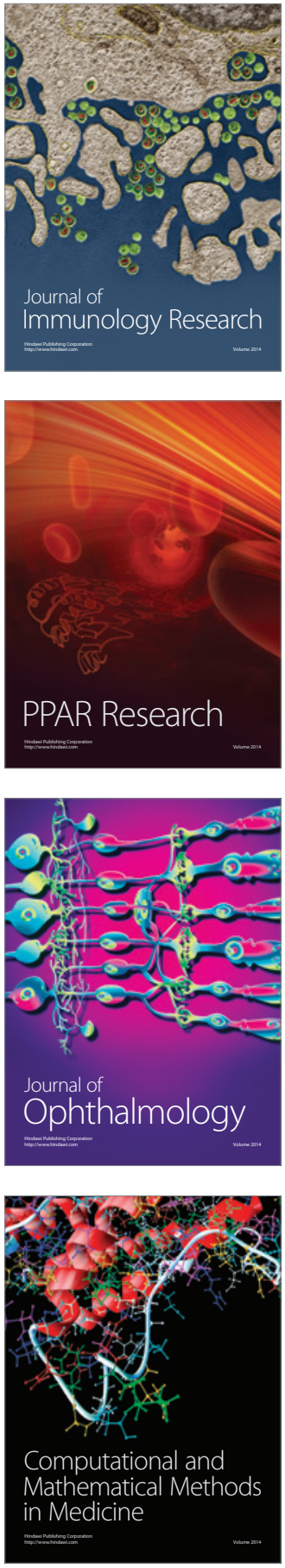

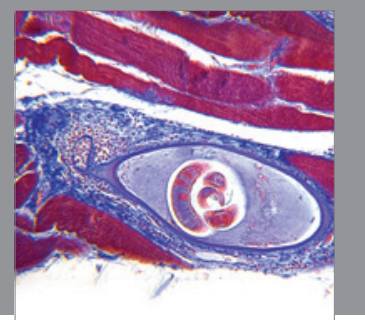

Gastroenterology

Research and Practice
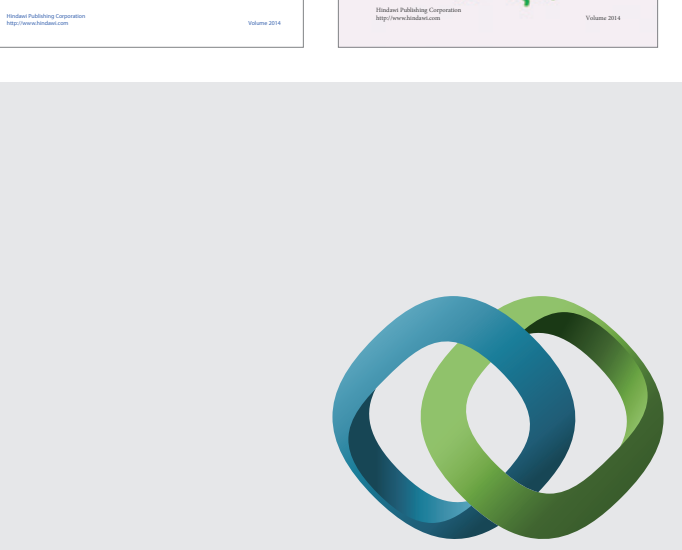

\section{Hindawi}

Submit your manuscripts at

http://www.hindawi.com
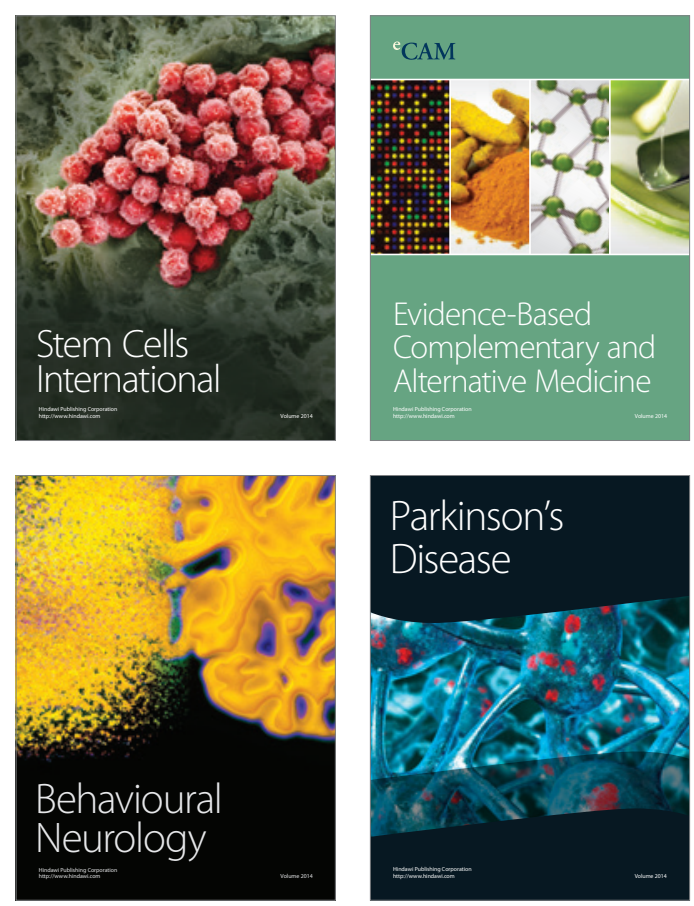

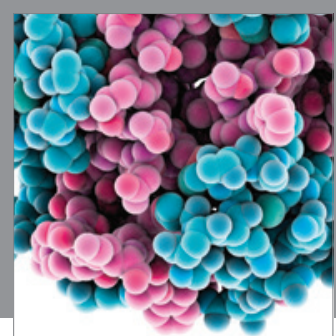

Journal of
Diabetes Research

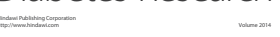

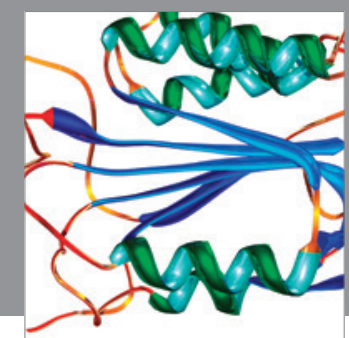

Disease Markers
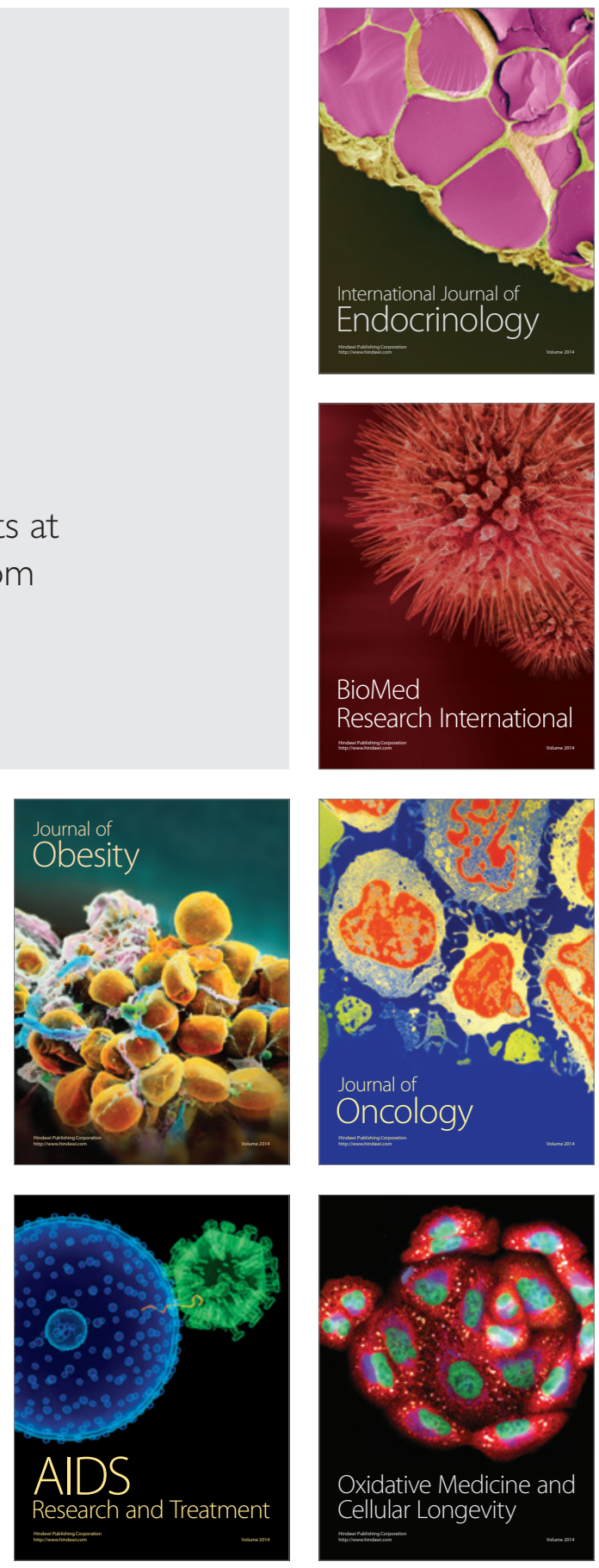